\title{
The Feeling of Inadequacy and the Metaphysical Hope
}

\author{
Spyridoula G. Kostara \\ Department of Pastoral Studies, Supreme Ecclesiastical Academy of Athens, Athens, Greece \\ Email: spykostara@gmail.com
}

How to cite this paper: Kostara, S.G. (2021). The Feeling of Inadequacy and the Metaphysical Hope. Psychology, 12, 1089-1095. https://doi.org/10.4236/psych.2021.127066

Received: June 18, 2021

Accepted: July 18, 2021

Published: July 21, 2021

Copyright $\odot 2021$ by author(s) and Scientific Research Publishing Inc. This work is licensed under the Creative Commons Attribution International License (CC BY 4.0).

http://creativecommons.org/licenses/by/4.0/

(c) (i) Open Access

\begin{abstract}
The purpose of this brief study is to indicate that humans are distinguished from all other beings, mainly due to their metaphysical nature and because-unlike other beings-they are able to communicate rather than merely associate. More importantly, human communication takes various forms: communication with beings, with peers, with the self as well as with the cause for the self, that is God. Of course, scientists analyse obvious forms of communication or ones that can only be perceived by the senses, similar to the ones that occur within the context of human interactions and social conventions. A different approach was indicated by Karl Jaspers, one of the pioneer scholars who rejected uncritical positivism. This approach showed that there is something more profound than what meets the eye, therefore illuminating new directions for the study of Psychology and expanding its horizons. Beginning with Plato, who characterizes human existence as "binary" and "bilateral", and ending with the Christian Word of Saint Paul, which suggests that we seek "the future city"-our home, we approach the feeling of human inadequacy in relation to the metaphysical hope. Mankind-with the aim to achieve ideal goals as a creative motive-adopts a series of attitudes and decisions, capable to influence the course of social and historical evolution. This struggle stems from the human longing to exalt and rise above the world of perceived reality and to walk towards an alternative world, that of metaphysical hope.
\end{abstract}

\section{Keywords}

Feeling of Inadequacy, Metaphysical Hope, Communication, Ideal Goals

\section{Introduction}

The purpose of this brief study is to indicate that humans are distinguished from all other beings, mainly due to their metaphysical nature and because-unlike 
other beings-they are able to communicate rather than merely associate. More importantly, human communication takes various forms: communication with beings, with peers, with the self as well as with the cause for the self, that is God, as enlightenment and window to the metaphysical super-empirical reality. It also endeavours to demonstrate that humans, wishing to disengage from transience, conventionality and degeneration, and employing ideal goals as a creative motive, adopt a series of attitudes and decisions which allow them to influence the course of social and historical evolution.

Beginning with Plato, who characterizes human existence as "binary" and "bilateral", and redemptively ending with the Christian Word of Saint Paul, which suggests that we seek "the future city"-our home, we approach the feeling of human inadequacy in relation to the metaphysical hope. It is shown that the human struggle for improvement and change stems from a primordial urge towards the transcendence of the limit, from the nostalgia to emerge from the world of perceived reality and walk towards another world, that of the metaphysical hope.

Deep down, one can discern the attempt of this paper to uncover something of the existential essence; humans exist as beings and come to be as essence, given their long-evolving course and dynamism, which is evident in each phase or stage of their life. Of course, it aspires to cause further interest and research conduct.

\section{The Desire for the Eternal and the Communication: Two Creative Human Tendencies of the Soul}

We thirst for the light, the freedom and the liberation from anything that confine us. This is the reason why we perceive individuality - which is both a creation and a carrier of life-as a restrain, a barrier and a detachment from the whole and the universal. This desire for the illimitable is the most probable reason for the creation of society and the most pressing cause for the communication among people. Indeed, all the great human achievements were realised on the basis of a common creative life and in the context of spiritual communication (Louvaris, 1949; Bühler, 1968).

Society is a living organism, the inner structure of which is rather complicated. Every individual, integrated into a certain whole, influences and is influenced by others concurrently. Every whole that consists of and is based on individuals-or better yet, people, since we are talking about mankind-regulates those inevitable influences. This weaves a thick net of interaction which engulfs the individuals and brings to life organised social groups with specific aims, set by the human conscience. Those aims do not emerge unsolicited; rather, they are invented and materialised consciously by the people. In this way, along with using communication as a tool, History is created and Civilization is founded. Society, history and civilization are not static. They are organic and ever-evolving, they progress, they move forward. On the basis of this relentless evolution lays the communicative spirit of the human being (Popper, 1982). 


\section{The Humans as Citizens of Two Worlds}

\subsection{The Ideal Goals as a Motive of Creation and Disengagement from Conventionality and Degeneration}

Civilization is a uniform sum of principles, values, ideas and ideals, which have been realised or attempted to be realised throughout history through the partnership among people. One of the main incentives that lead the humans towards creation in all the aspects of life is the optimum goals which they seek to accomplish, wishing to unbind themselves from transience, conventionality and degeneration. For, although they are creations of nature, they possess the grace of spirit, thus being gifted with the capacity to intervene and change nature, to transform the world, to-a certain extend-foresee and to plan the future. They are capable of introducing a system of rules, conditions and laws, as well as to make decisions, which means they hold themselves morally accountable while nature is neither moral nor immoral. The humans have introduced the concept of principle to the natural world despite being but "part" of it. No decision comes from either nature or the events. It is possible, therefore, for the people to adopt a series of attitudes and decisions with which to influence, either positively or negatively, the course of social and historical development, as well as their personal destiny: it is a human duty not to accept the appointed context of life heedlessly and uncritically, but to always find room for improvement and to strive for partial or full change (Weizsäcker, 1969).

\subsection{The Feeling of Inadequacy, the Struggle for Improvement and the Metaphysical Hope}

This struggle for improvement and change stems from a primal impulse to rise above the limit, from man's longing to emerge from the world of the perceived reality and walk toward a different world, that of the metaphysical hope. Even in Nietzsche's anti-metaphysical soul, there lives a deep and enduring desire for the world of the super-perceived reality, which calls: "Where is my homeland? This I seek and after it I ask, without ever finding it!" "Oh, Zarathustra, you are more pious than you know" (Nietzsche, 1978).

This inquisitive call confirms the world-viewing and bio-theoretical perception of Plato and Democritus, suggesting that the man is "bilateral", "citizen" of two worlds, holder of them both: the natural world, where coercion reigns, and the spiritual world, where freedom reigns (Plato, 2013a; Plato, 2013b). For this reason, humans may partake in eternal life though they live in transience. A feeling of inadequacy urges them to seek sanctification for their existence because the world of numbers, the world of objective calculations, that is, the world of science does not satisfy them, does not compensate them; nor does it make them rise above the pedestrian and often cruel everyday life.

\subsection{The Double Communicative Role of Memory}

Sample of the quality difference between these two worlds is memory, this inva- 
luable function of the soul, which does not follow the natural law and yet it founds the most blessed forms of communication. Memory makes all that seem far away come close, it transforms the old into the new, it transmutes the past into the future (Zakay, 2016). It abolishes space and time. Thus, while we are miles away from a loved one, we are still always near them. The dear shadows of the ones who have left "for ever" become the most luminous, the most consoling and the most nostalgic presence and companion. In absolute silence, one thinks of them, communes with them, drawing the indelible imprints from the depths of memory and the heart.

This communication, as a window to transcendence, to the metaphysical, super-empirical reality, is neither opportunistic nor frivolous. It stems from the innermost depths of the soul and expels its loneliness. It attracts and invites continuously. It fills the soul with warmth and spiritual beauty, it dispels the polar shudder of abandonment and lamentable despair and, most importantly, it detaches and "unburdens" it from the common life, which prevents from this crucial examination due to the daily goals and various concerns. It is through this examination, though, that this form of communication nullifies the temporal and territorial distances, gaining the ultimate approximation to the real, the metaphysical home. In the words of Saint Paul: "For they that say these things do signify that they seek a country." (Paul, Epistle to the Hebrews, 11:14). "For, we have not here a lasting city: but we seek one that is to come." (Paul, Epistle to the Hebrews, 13:14).

\section{Uncritical Positivism and Communicational Truth}

Science and often Psychology itself, depending on the direction it follows, turn to and analyse forms of communication that are either obvious or perceived by the senses, like the ones that occur by consequence in the context of natural processes, human interaction and social conventions. They see everything as a natural occurrence, everything that is not palpable as non-existent and everything that is not extendable or tangible as unsustainable. They deem unreal everything that cannot be counted, cannot be calculated or cannot be measured. What the scientists fail to explain providing evidence is how it happens and why what is true for the spirit of the human beings is not true for their body. Everything corporal, extendable, conceivable may only be found in one place, that is, it cannot be "here" and "there" at the same time. The spirit, on the other hand "... blows wherever it pleases. You hear its sound, but you cannot tell where it comes from or where it is going" (John 3:8).

\section{The Need for the Transcendence of Inadequacy and the Genuine Communication in Karl Jaspers}

In the modern era, there have been scholars who rejected the arrant and uncritical positivism, they showed that there is something deeper than what meets the eye, they opened new paths to Psychology and broadened its horizons (Spinelli, 
2007). Undoubtedly, one of the greatest pioneer researchers was Karl Jaspers (1883-1969) (Joranger, 2015), known as "the Psychologist of Communication", because one of the central themes he engaged with was Communication (Gordon, 2000).

Jaspers discusses the theme of communication mostly in five of his works: "Psychology of worldviews" (:Psychologie der Weltanschauungen, Berlin-Heidelberg 19605); "Philosophy" (:Philosophie, Göttingen-Heidelberg 19654), a three-volume work: volume I titled as "World Orientation", the chapter called "Communication" in volume II titled as "Illumination of Existence" (:Existenzerhellung), volume III titled as "Metaphysics” (:Metaphysik); “Philosophical Faith” (:Der philosophische Glaube, Zürich-München 19636); “Philosophical Faith and Revelation” (:Der philosophische Glaube angesichts der Offenbahrung, München 19734) and "A Short Course in Philosophical Thinking" (:Kleine Schule philosophischen Denkens, München 19752), on chapter 10 of which we may find a profound analysis on the Hymn to Love by the Apostle of Nations, St Paul.

According to Jaspers, the unadulterated truth can only be found in communication, which is a constant dialogue between I and You, without any of them threatening the autonomy of the other (Horn, 1993). Therefore, the self as a concept is a result of the co-existence with the other (Schnell, 2016). This dialogue takes place in five levels. The first level is that of the empirical existence, of the community and its conventions, its struggle to exist, its bonds, its vital interests, the efforts for pleasure and satisfaction, the unachievable happiness. The second level is that of the Conscience, where communication occurs between reason-conditioned individuals using the methods of argumentation which are agreed and based upon rational categories that can generally be applied to all people. The third level is that of the spirit, with communication being infused into the whole of the community of reflection under the light of an idea and its purpose to convince, having encompassed all the essentials that are needed to the journey towards fulfillment. The fourth level is that of the Hypostasis, referring to communication taking place unconditionally among people that wish to become themselves, that is, irreplaceable and unique individuals, who have acquired the sense of a universal security and the shipwreck of a worldly hypostasis in order to give way to the eternal and vigilant pursuit for the truth. Thus springs the need for transcendence. In the fifth and final level, the human being as Hypostasis stands before the Transcendence of silence; for "the worst thing in thought as well as communication is silence," as Jaspers (1960) claims.

\section{The Communication with the Divine as a Means of Enlightenment and Redemption for the Mankind}

Redemption from the transience, from the cruelty of perceptible things and from the nostalgia for eternity promote communication to a deeply mental need and desire to approach the will of the Divine. This is when communication channels into "the light of love which greets the angels" as Dante relates, announcing the 
dawn of a New Life. The blessed and sacred forces of esoteric life and awe, encouraged by the radiance of Transcendence, lead existence to the absolute illumination, create a pure discourse with God as a Saviour, and arm mankind with the "passion" for religious Faith.

Internalization becomes complete through absolute illumination. Everything becomes new and communication loses every trace of materialism. Instead, it is replaced by brotherhood-deep, true and unfeigned-in the form of genuine Love. In the words of Jaspers in his chapter "Kommunikation" (:Communication), "Do not welcome me, dearest, when I come and do not bid me farewell when I leave, for I never do I come whence I come and never do I leave whence I leave" (Jaspers, 1994).

Prayer is the discourse with the uppermost You, the abolition of every distance and "communion, communication" with God. Through communion in the form of Prayer, stifled are the tormented cries that spring from our depths and nullified are the sobs of our inner pain (Francis \& Evans, 1995; Spilka \& Ladd, 2013).

By means of faith, existence leaves Knowledge behind, it crucifies reason and earns its redemption and salvation: "Faith is the substance of things hoped for, the evidence of things not seen ..." (Paul, Epistle to the Hebrews 11:1). This is the foundation of a new religious existence, which overflows-in its fulfillment-with christian images and powers, and becomes carrier of a new, religiously inflamed life. In its center stands the Messiah, the suffering saviour of mankind from the sin and the arisen Conqueror of Death. The faith in the truth of the Passion and the Resurrection is overwhelming!

Indeed, "if Christ has not been raised, your faith is futile ..." (Paul, First Epistle to the Corinthians, 15:17). The Resurrection, however, through unshakable faith, is a tangible, warm, lively and vibrant reality. The same is true for the resurrection of the dead: ".. about the resurrection of the dead-have you not read what God said to you" (Matthew 22:31), "He is not the God of the dead but of the living ..." (Matthew 22:32). To the question as to why the corrupted body arises incorruptible, the rejected glorious and the sickly vigorous, the Hymnograph-Poet ventures an answer in the sixth Ode of Theophany (Epiphany) of our Lord, Katavasiae (January 6th): "For Christ with His presence saved the world from death.”

\section{Conclusion}

Communication, despite its dialectal transformations and semantic renderings, knows the absolute affirmation as delectable love and redemptive communion-discourse with the undying Light: the Way, the Life and the Truth. Something of their divine radiation which assures of the metaphysical certainty and soothes the tormented hearts, perhaps only the God-inspired, poetic pen of Symeon the New Theologian's could relate-along with the deepest essence of communication: "You have smitten me with yearning, O Christ, and by Your 
divine eros You have changed me ... Blessed are those who embrace Your beauty ... those who bow to You with delight ... The most graceful of the graceful I will then be ...". Those beautiful poetic words are of the noblest externalisations of human inadequacy, a call for connection with the Inconceivable and, at the same time, a hope to dwell in His gardens and a wish for salvation!

\section{Conflicts of Interest}

The author declares no conflicts of interest regarding the publication of this paper.

\section{References}

Bühler, K. (1968). Ausdruckstheorie. Das System an der Geschichte aufgezeigt. Stuttgart: G. Fischer.

Francis, L. J., \& Evans, T. E. (1995). The Psychology of Christian Prayer: A Review of Empirical Research. Religion, 25, 371-388. https://doi.org/10.1016/S0048-721X(05)80021-1

Gordon, R. D. (2000). Karl Jaspers: Existential Philosopher of Dialogical Communication. Southern Communication Journal, 65, 105-118. https://doi.org/10.1080/10417940009373161

Horn, H. (1993). Karl Jaspers (1883-1969). Prospects, 23, 721-739. https://doi.org/10.1007/BF02195146

Jaspers, K. (1960). Vernunft und Existenz. Fünf Vorlesungen. München: Piper Verlag. Jaspers, K. (1994). Philosophie: II, Existenzerhellung. München: Piper Verlag.

Joranger, L. (2015). Karl Jaspers' Interdisciplinary and Dual Psychopathology. Ideas in History. Journal of the Nordic Society for the History of Ideas, 8, 75-103.

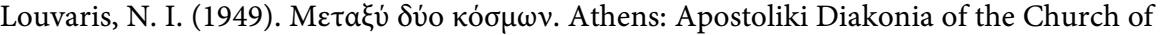
Greece.

Nietzsche, F. (1978). Götzendämmerung; Der Antichrist. Ecce homo [u.a.]. Stuttgart: Kröner.

Plato. (2013a). The Euthydemus of Plato. (305c) (E. H. Gifford, Ed.). Cambridge: Cambridge University Press. (Original work published ca. 384 BCE).

Plato. (2013b). Laws. (878b) (R. G. Bury, Ed.). London: Heinemann. (Original Work Published ca. $340 \mathrm{BCE})$.

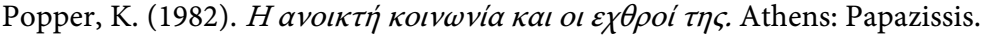

Schnell, T. (2016). Psychologie des Lebenssinns. Heidelberg: Springer. https://doi.org/10.1007/978-3-662-48922-2

Spilka, B., \& Ladd, K. L. (2013). The Psychology of Prayer: A Scientific Approach. New York, NY: Guilford Press.

Spinelli, E. (2007). Practising Existential Psychotherapy: The Relational World. London: Sage Publications Ltd.

Weizsäcker, C. F. (1969). Kritik der Wissenschaften: Tonbandnachschrift Der Vorlesungen an Der Universität Hamburg Im Wintersemester 1968/69. Hamburg: Print.

Zakay, D. (2016). Psychological Time. In B. Mölder, V. Arstila, P. Øhrstrøm (Eds.), Philosophy and Psychology of Time. Studies in Brain and Mind (pp. 53-66). Switzerland: Springer. 